\title{
F. C. GILCHRIST'S DIARY - FORT QU'APPELLE $1883-1896$
}

by Mary and C. Stuart Houston, 863 University Drive, Saskatoon

Few items in the Saskatchewan Archives contain more of interest to the naturalist than the 496-page typewritten copy of the diary of $F$. C. Gilchrist. Gilchrist homesteaded in 1883 on the southwest quarter of 12-23-15W2, 10 miles north of Pasqua Lake (formerly Qu'Appelle Lake), on the site of the present railway between Dysart and Cupar. During the Riel Rebellion of 1885 he moved his family into Fort Qu'Appelle and in 1886 took up residence at the base of B-Say-Tah point, $3 \frac{1}{2}$ miles west of Fort Qu'Appelle on the south shore of Echo Lake. His diary notes that he could skate to Fort Qu'Appelle on the winter ice in 11 minutes.

The diary began November 1, 1883 and continued until March 13, 1896, one week before he died of pneumonia at his home at the relatively early age of 36 years. He was a contemporary of George F. Guernsey (see: "Saskatchewan's First Resident BirdWatcher", Blue Jay 16:52-54, June 1958) who was at times his shooting partner and at other times his political opponent.

In 1884 Gilchrist was appointed fisheries overseer of the Qu'Appelle Lakes and tributaries. In May 1891 he was appointed Inspector of Fisheries for the Northwest Territories and continued in this position until his death. He visited Crooked Lake and Round Lake in October 1889 and Last Mountain Lake in July and November 1890. In July 1891 a threeweek trip took him to Edmonton, Battleford and Fort Carlton (then deserted), thence by canoe to Prince Albert and to Regina and Troy (now Qu'Appelle) by train. In June 1894 he travelled down the Saskatchewan by canoe, visiting Fort a la Corne, Nipawin and Cumberland House; on June 26, 1894 he met J. B. Tyrrell of the Canadian Geological Survey at Chemawawin. He published an interesting article on "The Tullibee" in
Forest and Stream of April 7, 1892, in addition to an article on "Sawdust in Ontario Streams" in the same publication in early 1890.

As a youth, in Port Hope, Ontario, Gilchrist had done some taxidermy. When the 20-member party of the British Association visited Fort Qu'Appelle on August 13, 1884, Sir Bedford Pim's son asked Gilchrist to collect some bird skins for him. He attempted to mount a pelican for the reception of Sir Hector Langevin on August 25, 1884 but found this was not possible with the materials at hand. He mentions mounting an owl, two blackbirds, a Yellow-headed Blackbird and three gulls in 1884-85. Some of the fish he mounted were on display in the Fisheries Department in Ottawa. Twice his diary mentions letters written to the Smithsonian Institution.

Many of his diary entries deal with duck shooting. His most successful days were as follows: November 2, 1887: "54 ducks, almost all bluebills"; October 27, 1889: "53 ducks, principally bluebills and mallards";

November 7, 1889: "Killed about 50 ducks this a.m.";

November 14, 1890: "Jack killed 45 bluebills and I killed 17."

October 29, 1892: "Got 47 good ducks".

This was before the days of game laws and some shooting was done in the spring. For example, the entry of May 14, 1890 reads: "Killed 13 bluebills, 7 redheads and 1 canvasback. Could have killed many more bluebills but did not want them." He killed 27 additional ducks that month.

Over the years, two yellowlegs, four Golden Plover, one American Avocet, two Sandhill Cranes and 17 unidentified plover figured in the bag. He did little upland game shooting. Sharptailed Grouse ("prairie chicken") were scarce in the winter of 1885-86 and on February 15, 1886 he remarked that he had "seen but five." 
Their numbers improved and on July 25,1889 , he saw about 40 . His largest bag of Sharp-tailed Grouse was 10 shot on November 30, 1892. Many years he shot only a single Sharptailed Grouse, in either November or December. Over the years he mentioned shooting only seven geese.

There is an interesting note from "Muskago Lake", his name for the marshy western end of Pasqua Lake, dated June 16, 1889: "A much greater number of ducks than usual are breeding here and the Indians are murdering them all day. They wade around and kill the young with sticks and the old with shot."

Birds mentioned in the diary include 44 species. Some interesting entries, chiefly spring arrival dates and fall departure dates, are as follows:

White Pelican: "April 15, 1889. 66 pelicans passed over this evening; I never saw them come so early before." "April 15, 1895. 15 pelicans came."

DOUBLE-CRESTED CORMORANT: "April 24,1889 . Saw a number of cormorants."

WHISTLING SWAN: Late fall dates of Nov. 4, 1890, and Nov. 15, 1894

CANADA Goose: Spring dates of April 5, 1885 and April 4, 1895.

Mallard: Spring dates of April 5, 1885 ; April 11, 1886 ; April 9, 1887 ; April 15, 1889; March 30, 1895. Late fall shooting, November 15, 1889

GADWALL AND AMERICAN WIDGEON : Marked southward migration of these two species noted October 13, 1891.

PINTAIL: Spring date of April 1, 1895.

Redhead AND CanvasbaCK: Late fall shooting, October 15, 1889.

LESSER Scaup: Spring date of April 5 , 1895. Late fall shooting on November 22, 1887, and November 21 in 1889 and 1890 .

BUFFLEHEAD: Late fall shooting, October 28, 1886.

RUDDY DUCK: Late fall shooting, October 28, 1886.

Marsh HaWK: Spring dates of March 30, 1886; April 10, 1889; April 15, 1895 .
SpARRow HAWK : Spring arrival, A pril $8,1889$.

SANDHILL CRANE: "Sept. 19, 1885. There is a flock of Sandhill Cranes on my stubble all the time; when one flock goes, another comes." "Sept. 21, 1885: Shot 2 Sandhills with shotgun."

AMERICAN COOT: Late fall shooting, November 11, 1889.

KILLDEER: Spring dates of April 18, 1887; April 7, 1890; April 13, 1895.

Yellowlegs (species?): Spring dates April 16, 1884 and April 14, 1887.

A MERICAN A vocet: "May 4, 1889: Shot an avocet".

BonAPARTE's Gull: “June 4, 1885: I have put up three Bonaparte's gulls." (It is possible that these were Franklin's Gulls - CSH).

SNOWY GWL: One mentioned as seen February 14, 1884.

BANK SWALlow: Spring dates of May 7, 1885 and April 22, 1889.

CaMmon Crow: Spring dates of April 3, 1884 ("plenty") ; April 4, 1885 (18) ; March 30, 1886 (2) ; April 2, 1887 (some on lake ice); April 6, 1888 (heard); April 3, 1890; March 31, 1893 (a number); March 29, 1895.

RoBin: Spring dates of April 16, 1886; April 18, 1887 (a large number) ; April 14, 1889 (a number); April 7, 1890; April 19, 1892 (in great plenty) ; April 12, 1895.

Western Meadowlark: Spring dates of April 16, 1884; A pril 10, 1885; April 13, 1886; April 7, 1890.

Baltimore Oriole: Spring date of May 16, 1895.

COMMON Grackle: Spring date of April 9, 1895.

Tree Sparrow: Migration dates for "Chipping Sparrows" likely are referable to this species. April 10, 1885; April 3, 1887; April 2, 1890 ; March 24, 1892; March 27, 1895.

Song SPARRow: Spring dates of April 2, 1884; April 8, 1885; April 18, 1887; April 7, 1895.

We wish to thank D. H. Bocking of the Saskatchewan Archives Office, University of Saskatchewan, for his assistance, and Mrs. Maude Adams of Victoria, B.C., for additional information. 